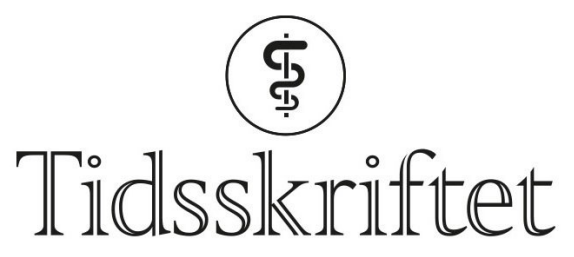

DEN NORSKE LEGEFORENING

\title{
Gammelt blod er like godt som nytt
}

FRA ANDRE TIDSSKRIFTER

ØYVIND STOPLE SIVERTSEN

Tidsskriftet

Det bedrer ikke overlevelsen hos kritisk dårlige pasienter om man gir dem de ferskeste blodposene. Det viser en stor multisenterstudie.

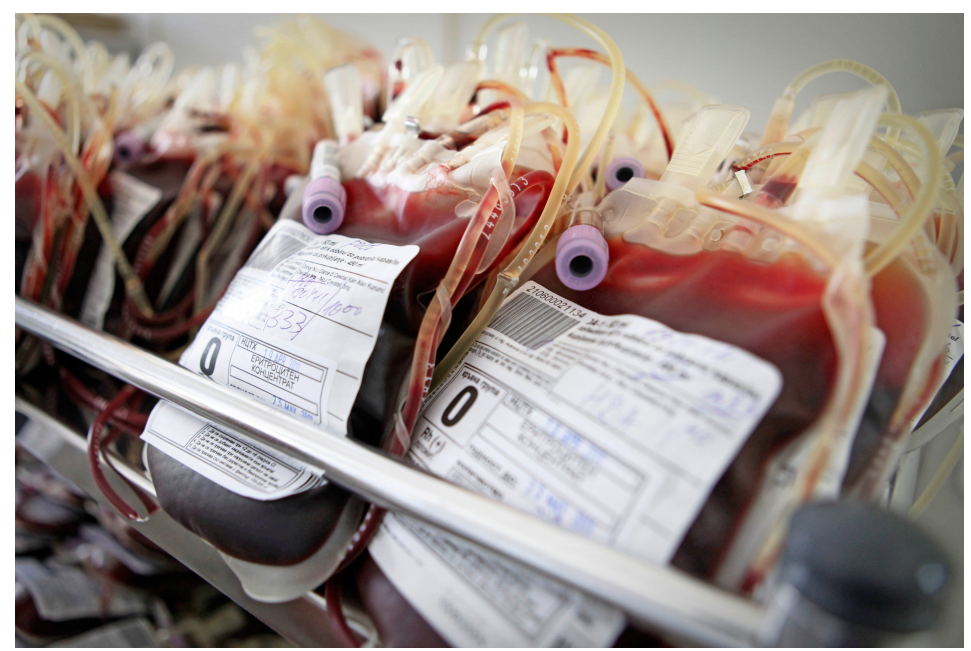

Illustrasjonsfoto: AP Photo/Valentina Petrova/NTB scanpix

I en studie som nylig er publisert i New England Journal of Medicine fikk rundt 5 ooo pasienter som trengte blodoverføring enten erytrocytter som gjennomsnittlig var lagret i 11,8 dager eller erytrocytter som gjennomsnittlig var lagret i 22,4 dager (1). Alle pasientene var henvist til et akuttmottak på grunn av akutt oppstått sykdom og innlagt i sykehuset i mer enn 24 timer. go dager etter blodoverføringen var dødeligheten omtrent lik i de to gruppene. Dette er i samsvar med tidligere undersøkelser gjort hos pasienter som ikke var så kritisk syke (2, 3).

- Under lagring i blodpose blir erytrocyttene stivere, de endrer overflatestrukturer, oksygenaffiniteten øker, kalium lekker ut og noen celler går i oppløsning. Alt indikerer at "gamle erytrocytter» må være ugunstig for pasientene, forklarer Tor Hervig, som er overlege ved Avdeling for immunologi og transfusjonsmedisin ved Haukeland universitetssykehus og professor ved Universitetet i Bergen.

- Likevel viser altså gode kliniske studier som denne at man ikke kan finne noen sikre negative effekter av å transfundere "gamle erytrocytter» til kritisk syke. Selv om man kan prøve å bortforklare resultatene med at forskjellen i lagringstid var relativt liten mellom gruppene i studien og at det dreide seg om i gjennomsnitt bare fire transfunderte enheter, holder dette ikke. De omfattende in vitro-forandringene i lagrede røde blodceller gir ikke 
utslag in vivo. Årsaken til dette store paradokset er fortsatt ukjent, sier Hervig.

LITTERATUR:

1. Cooper DJ, McQuilten ZK, Nichol A et al. Age of red cells for transfusion and outcomes in critically ill adults. N Engl J Med 2017. http://www.nejm.org/doi/full/10.1056/NEJMoa1707572\#tarticle (2.11.2017).

2. Heddle NM, Cook RJ, Arnold DM et al. Effect of short-term vs. long-term blood storage on mortality after transfusion. N Engl J Med 2016;375:1937-45. [PubMed][CrossRef]

3. Dhabangi A, Ainomugisha B, Cserti-Gazdewich C et al. Effect of transfusion of red blood cells with longer vs shorter storage duration on elevated blood lactate levels in children with severe anemia: the TOTAL randomized clinical trial. JAMA 2015; 314: 2514 - 23. [PubMed][CrossRef]

Publisert: 12. desember 2017. Tidsskr Nor Legeforen. DOI: 10.4045/tidsskr.17.0930

(C) Tidsskrift for Den norske legeforening 2020. Lastet ned fra tidsskriftet.no 